\title{
Promoting Effect of Cerium Oxide on the Catalytic Performance of Yttrium Oxide for Oxidative Coupling of Methane
}

\author{
Masaaki Haneda ${ }^{1,2 *}$, Yuya Katsuragawa ${ }^{1}$, Yuichiro Nakamura ${ }^{1,2}$ and Atsuya Towata ${ }^{3}$ \\ ${ }^{1}$ Advanced Ceramics Research Center, Nagoya Institute of Technology, Tajimi, Japan, ${ }^{2}$ Frontier Research Institute for \\ Materials Science, Nagoya Institute of Technology, Nagoya, Japan, ${ }^{3}$ Magnetic Powder Metallurgy Research Center, National \\ Institute of Advanced Industrial Science and Technology, Nagoya, Japan
}

The promoting effect of $\mathrm{CeO}_{2}$ on the catalytic performance of $\mathrm{Y}_{2} \mathrm{O}_{3}$, which is moderately active catalyst, for the oxidative coupling of methane (OCM) reaction was investigated. The addition of $\mathrm{CeO}_{2}$ into $\mathrm{Y}_{2} \mathrm{O}_{3}$ by coprecipitation method caused a significant increase in not only $\mathrm{CH}_{4}$ conversion but also $\mathrm{C}_{2}\left(\mathrm{C}_{2} \mathrm{H}_{6} / \mathrm{C}_{2} \mathrm{H}_{4}\right)$ selectivity in the OCM reaction. $\mathrm{C}_{2}$ yield at $750{ }^{\circ} \mathrm{C}$ was increased from $5.6 \%$ on $\mathrm{Y}_{2} \mathrm{O}_{3}$ to $10.2 \%$ on 3 mol\% $\mathrm{CeO}_{2} / \mathrm{Y}_{2} \mathrm{O}_{3}$. Further increase in the $\mathrm{CeO}_{2}$ loading caused an increase in non-selective oxidation of $\mathrm{CH}_{4}$ to $\mathrm{CO}_{2}$. A good correlation between the catalytic activity for the OCM reaction and
OPEN ACCESS

Edited by: Cristina Artini, Università di Genova, Italy

Reviewed by:

Toshiyuki Masui, Tottori University, Japan

Naoyoshi Nunotani,

Osaka University, Japan

*Correspondence:

Masaaki Haneda haneda.masaaki@nitech.ac.jp

Specialty section This article was submitted to Physical Chemistry and Chemical

Physics,

a section of the journa

Frontiers in Chemistry

Received: 17 July 2018 Accepted: 06 November 2018 Published: 22 November 2018

Citation:

Haneda M, Katsuragawa Y, Nakamura Y and Towata A (2018) Promoting Effect of Cerium Oxide on the Catalytic Performance of Yttrium Oxide for Oxidative Coupling of

Methane. Front. Chem. 6:581. doi: 10.3389/fchem.2018.00581 the amount of $\mathrm{H}_{2}$ consumption for the reduction of surface/subsurface oxygen species in the $\mathrm{H}_{2}$-TPR profile was observed, suggesting the possibility that highly dispersed $\mathrm{CeO}_{2}$ particles act as catalytically active sites in the OCM reaction. The ${ }^{16} \mathrm{O} /{ }^{18} \mathrm{O}$ isotopic exchange reaction suggested that the beneficial role of $\mathrm{CeO}_{2}$ in the $\mathrm{OCM}$ reaction is to promote the formation of active oxygen species via the simple hetero-exchange mechanism, resulting in the promotion of $\mathrm{CH}_{4}$ activation.

Keywords: oxidative coupling of methane, cerium oxide, yttrium oxide, ${ }^{16} \mathrm{O} /{ }^{18} \mathrm{O}$ isotopic exchange, $\mathrm{H}_{2}$-TPR

\section{INTRODUCTION}

Methane, which is the main constituent of natural gas, is an abundant hydrocarbon resource for energy and chemicals. Since methane is the most stable hydrocarbon, the selective oxidation to the chemicals seems to be difficult compared with other hydrocarbons. Therefore, in many cases, methane is first partially oxidized to synthesis gas $\left(\mathrm{CO}+\mathrm{H}_{2}\right)$, and then converted to the chemicals such as methanol, acetic acid, light hydrocarbons and so on. This is well-known process as C1 chemistry.

On the other hand, as for the direct conversion of methane to the chemicals, oxidative coupling of methane (OCM) is regarded as energy efficient and simple chemical process for the production of higher hydrocarbons, especially, ethane and ethylene (Lunsford, 1995). The development of highly active OCM catalyst has been continuously performed over the past few decades (Hutchings et al., 1989; Arndt et al., 2011; Takanabe, 2012; Farrell et al., 2016) since the pioneering works of Keller and Bhasin (1982). The OCM reaction proceeds via the formation of methyl radicals formed by the reaction of methane with active oxygen species and subsequent coupling the methyl radicals (Dubois and Cameron, 1990). Therefore, designing the catalyst surface to create the active oxygen species such as $\mathrm{O}^{-}, \mathrm{O}_{2}^{2-}$, and $\mathrm{O}^{2-}$ for the OCM reaction must be the important strategy to develop highly active catalysts (Kumar et al., 2016). 
Cerium oxide $\left(\mathrm{CeO}_{2}\right)$ is well-known material showing reversible oxygen release/absorb properties, so-called OSC (oxygen storage capacity) (Trovarelli, 1996), leading us to the expectation that $\mathrm{CeO}_{2}$ can promote the activation of methane and then improve the catalytic performance for the OCM reaction. The promoting effect of $\mathrm{CeO}_{2}$ on the OCM reaction has already been reported by many researchers. For example, Tang et al. (2011) reported that the addition of $\mathrm{CeO}_{2}$ into $\mathrm{Li} / \mathrm{MgO}$ caused an increase in the $\mathrm{CH}_{4}$ conversion at lower reaction temperature with little change in $\mathrm{C}_{2}$ selectivity. They explained the promoting effect of $\mathrm{CeO}_{2}$ by oxygen activation caused via the electron transfer between $\mathrm{Ce}^{4+} / \mathrm{Ce}^{3+}$ and $\mathrm{Li} / \mathrm{MgO}$. A similar promoting effect of $\mathrm{CeO}_{2}$ was reported for $\mathrm{Na} / \mathrm{CaO}$ (Pacheco Filho et al., 2000) and $\mathrm{Li} / \mathrm{MgO}$ (Elkins et al., 2016). In case of alkali-doped catalysts, $\mathrm{Li}^{+} \mathrm{O}^{-}$and $\mathrm{Na}^{+} \mathrm{O}^{-}$sites are proposed to participate in oxygen activation (Ito et al., 1985; Lin et al., 1986). Therefore, the role of $\mathrm{CeO}_{2}$ is suspected to improve the catalytic ability of $\mathrm{Li}^{+} \mathrm{O}^{-}$and $\mathrm{Na}^{+} \mathrm{O}^{-}$sites through the electronic interaction. On the other hand, Rane et al. (2006) investigated the additive effect of rare earth elements ( $\mathrm{La}, \mathrm{Sm}$, $\mathrm{Ce}, \mathrm{Nd}$, and $\mathrm{Yb}$ ) on the OCM activity of $\mathrm{CaO}$, and found that $\mathrm{CeO}_{2}$ is not good additive for the formation of $\mathrm{C}_{2}$ products. This is probably due to the high ability of $\mathrm{CeO}_{2}$ for the complete oxidation of $\mathrm{CH}_{4}$ to $\mathrm{CO}_{2}$ (Ferreira et al., 2012; Xu et al., 2018).

Recently, we have investigated that similarity of catalytically active sites for oxidative coupling of methane (OCM) and NO decomposition, and found that the catalysts showing the activity for the latter reaction are also active for the former reaction (Haneda et al., 2018). We also reported that the addition of small amount of $\mathrm{CeO}_{2}$ into $\mathrm{Ba} / \mathrm{Y}_{2} \mathrm{O}_{3}$ causes a significant increase in the NO decomposition activity (Doi et al., 2015), suggesting the possibility that $\mathrm{CeO}_{2}$ behaves as effective promoter for the OCM reaction. In this study, we prepared $\mathrm{CeO}_{2}$-promoted $\mathrm{Y}_{2} \mathrm{O}_{3}$ as the OCM catalyst by various methods, and found that $\mathrm{CeO}_{2} / \mathrm{Y}_{2} \mathrm{O}_{3}$ prepared by coprecipitation method showed the highest OCM activity. The active state and the role of $\mathrm{CeO}_{2}$ in the OCM reaction are discussed on the basis of its catalyst characterizations.

\section{EXPERIMENTAL}

\section{Catalyst Preparation}

A plural $\mathrm{CeO}_{2}$-promoted $\mathrm{Y}_{2} \mathrm{O}_{3}$ catalyst was prepared by coprecipitation, homogeneous precipitation, impregnation and hydrothermal methods. The loading of $\mathrm{CeO}_{2}$ was fixed at $3 \mathrm{~mol} \%$, except for the case of coprecipitation method. The details of $\mathrm{CeO}_{2} / \mathrm{Y}_{2} \mathrm{O}_{3}$ catalysts as well as $\mathrm{Y}_{2} \mathrm{O}_{3}$ itself prepared in the present study are summarized in Table 1 .

\section{Yttrium Oxide $\left(\mathrm{Y}_{2} \mathrm{O}_{3}\right)$}

$\mathrm{Y}_{2} \mathrm{O}_{3}$ was prepared by precipitation method using yttrium(III) nitrate and ammonia aqueous solution, followed by drying and calcination at $800^{\circ} \mathrm{C}$ for $5 \mathrm{~h}$ in air.

\section{Coprecipitation Method $\left[\mathrm{CeO}_{2} / \mathrm{Y}_{2} \mathrm{O}_{3}(\mathrm{CP})\right]$}

An aqueous solution of ammonia $\left(10 \% \mathrm{NH}_{4} \mathrm{OH}\right.$, FUJIFILM Wako Pure Chemical Corporation) as a precipitation agent was added to an aqueous solution of yttrium(III) nitrate [Y $\left(\mathrm{NO}_{3}\right)_{3} \cdot 6 \mathrm{H}_{2} \mathrm{O}$, FUJIFILM Wako Pure Chemical Corporation], and ammonium cerium(IV) nitrate $\left[\left(\mathrm{NH}_{4}\right)_{2} \mathrm{Ce}\left(\mathrm{NO}_{3}\right)_{6}\right.$, FUJIFILM Wako Pure Chemical Corporation] at room temperature. The precipitate thus obtained was washed with distilled water, followed by drying and calcination at $800^{\circ} \mathrm{C}$ for $5 \mathrm{~h}$ in air. The loading of $\mathrm{CeO}_{2}$ was changed from 1 to $10 \mathrm{~mol} \%$. The samples are abbreviated as $\mathrm{CeO}_{2}(x) / \mathrm{Y}_{2} \mathrm{O}_{3}(\mathrm{CP})$, where $x$ is the loading of $\mathrm{CeO}_{2}$.

\section{Homogeneous Precipitation Method $\left[\mathrm{CeO}_{2} / \mathrm{Y}_{2} \mathrm{O}_{3}\right.$ (HP)]}

The precipitation of yttrium and cerium hydroxides was obtained by adding urea $\left[\mathrm{CO}\left(\mathrm{NH}_{2}\right)_{2}\right.$, FUJIFILM Wako Pure Chemical Corporation] to an aqueous solution of yttrium(III) nitrate and cerium(III) nitrate $\left[\mathrm{Ce}\left(\mathrm{NO}_{3}\right)_{3} \cdot 6 \mathrm{H}_{2} \mathrm{O}\right.$, FUJIFILM Wako Pure Chemical Corporation] and stirring at $90^{\circ} \mathrm{C}$ for $24 \mathrm{~h}$, and then washed with distilled water, followed by drying and calcination at $800^{\circ} \mathrm{C}$ for $5 \mathrm{~h}$ in air.

\section{Impregnation Method $\left[\mathrm{CeO}_{2} / \mathrm{Y}_{2} \mathrm{O}_{3}(\mathrm{l})\right]$}

The deposition of $\mathrm{Ce}$ ions onto $\mathrm{Y}_{2} \mathrm{O}_{3}$ was carried out by impregnating $\mathrm{Y}_{2} \mathrm{O}_{3}$ powder, which was prepared by precipitation method as mentioned above, with an aqueous solution of cerium(III) nitrate, followed by drying and calcination at $800^{\circ} \mathrm{C}$ for $5 \mathrm{~h}$ in air.

\section{Hydrothermal Method $\left[\mathrm{CeO}_{2} / \mathrm{Y}_{2} \mathrm{O}_{3}(\mathrm{HT})\right]$}

The oleate solution prepared by dissolving potassium oleate $\left(\mathrm{C}_{17} \mathrm{H}_{33} \mathrm{COOK}, 19 \%\right.$ solution, FUJIFILM Wako Pure Chemical Corporation) with distilled water was added to an aqueous solution of yttrium(III) nitrate and ammonium cerium(IV) nitrate at room temperature under vigorously-stirred condition, followed by addition of ammonia aqueous solution. The mixture solution thus obtained was transferred to a Teflon vessel and then treated at $200^{\circ} \mathrm{C}$ for $6 \mathrm{~h}$ in an autoclave. The product thus obtained was washed with distilled water, followed by drying and calcination at $800^{\circ} \mathrm{C}$ for $5 \mathrm{~h}$ in air.

\section{Catalyst Characterizations}

$\mathrm{X}$-ray diffraction (XRD) patterns were recorded using a Rigaku MiniFlex diffractometer with $\mathrm{Cu} \mathrm{K \alpha}$ radiation at $30 \mathrm{kV}$ and $15 \mathrm{~mA}$. The scanning was done from $2 \theta=15-65^{\circ}$ at a speed of $1 \mathrm{deg} \mathrm{min}^{-1}$. The BET surface area of the catalysts was determined by $\mathrm{N}_{2}$ physisorption at liquid nitrogen temperature using a BELSORP mini-II, after evacuating the samples at $300^{\circ} \mathrm{C}$ for $1 \mathrm{~h}$. Raman spectra were measured with a MicroRAM300/NK (Lambda Vision) equipped with a TE-cooled charge coupled device (CCD) detector and a green laser $(\lambda=$ $532 \mathrm{~nm}$ ) under the ambient atmosphere. Direct observation of $\mathrm{CeO}_{2} / \mathrm{Y}_{2} \mathrm{O}_{3}(\mathrm{CP})$ samples by TEM was performed with a JEM2100 (JEOL) operating at an acceleration voltage of $200 \mathrm{kV} . \mathrm{H}_{2}$ TPR measurement was conducted to estimate the reducibility of the catalysts (Haneda et al., 2015). The TPR profiles were obtained from room temperature to $800^{\circ} \mathrm{C}$ in a $30 \mathrm{~cm}^{3} \mathrm{~min}^{-1}$ flow of $5 \% \mathrm{H}_{2} / \mathrm{Ar}$ at a heating rate of $10{ }^{\circ} \mathrm{C} \mathrm{min}^{-1}$. The consumption of $\mathrm{H}_{2}$ was monitored using a thermal conductivity detector (TCD). 
TABLE 1 | Physico-chemical properties of $\mathrm{CeO}_{2} \mathrm{~N}_{2} \mathrm{O}_{3}$.

\begin{tabular}{llcc}
\hline & Preparation method & Crystallite size ${ }^{\text {a }}(\mathbf{n m})$ & BET surface area $\left(\mathbf{m}^{\mathbf{2}} \mathbf{g}^{\mathbf{- 1}}\right.$ ) \\
\hline $\mathrm{Y}_{2} \mathrm{O}_{3}$ & Precipitation using NH & 40.0 & 23.9 \\
$\mathrm{CeO}_{2} / \mathrm{Y}_{2} \mathrm{O}_{3}(\mathrm{CP})$ & Coprecipitation using NH & 25.1 & 26.3 \\
$\mathrm{CeO}_{2} / \mathrm{Y}_{2} \mathrm{O}_{3}(\mathrm{HP})$ & Homogeneous precipitation using urea & 25.3 & 27.5 \\
$\mathrm{CeO}_{2} / \mathrm{Y}_{2} \mathrm{O}_{3}(\mathrm{l})$ & Impregnation & 33.3 & 23.0 \\
$\mathrm{CeO}_{2} / \mathrm{Y}_{2} \mathrm{O}_{3}(\mathrm{HT})$ & Hydrothermal at $200^{\circ} \mathrm{C}$ & 9.7 & 13.0 \\
\hline
\end{tabular}

a The crystallite size of $\mathrm{Y}_{2} \mathrm{O}_{3}$ was calculated from the XRD peak, given in Figure 1, from the (222) plane using Scherrer's equation.

The ${ }^{16} \mathrm{O} /{ }^{18} \mathrm{O}$ isotopic exchange reaction was carried out in a flow reactor system. An adequate amount of the sample $(30 \mathrm{mg}$ ) was installed in a quartz reactor, and then pretreated in a flow of $5 \% \mathrm{O}_{2} / \mathrm{He}$ at $600^{\circ} \mathrm{C}$ for $1 \mathrm{~h}$. After cooling to $100^{\circ} \mathrm{C}$ in flowing $5 \% \mathrm{O}_{2} / \mathrm{He}$, the sample was purged with $\mathrm{He}$ at $100^{\circ} \mathrm{C}$ for $30 \mathrm{~min}$. The reaction gas composed of $1 \%{ }^{18} \mathrm{O}_{2} / \mathrm{He}$ was fed to the catalyst at a rate of $20 \mathrm{~cm}^{3} \mathrm{~min}^{-1}$, and then the temperature was increased up to $600{ }^{\circ} \mathrm{C}$ at a heating rate of $10^{\circ} \mathrm{C} \mathrm{min}^{-1}$. The masses of $32\left({ }^{16} \mathrm{O}_{2}\right), 34\left({ }^{18} \mathrm{O}^{16} \mathrm{O}\right)$, and $36\left({ }^{18} \mathrm{O}_{2}\right)$ were continuously monitored by a quadrupole mass spectrometer (PFEFFER OminiStar).

\section{Activity Measurement}

The catalytic activity for oxidative coupling of methane was evaluated using a fixed-bed continuous flow reactor. The reaction gas composed of $44.4 \% \mathrm{CH}_{4}$ and $11.1 \% \mathrm{O}_{2}$ diluted with $\mathrm{He}$ as the balance gas was fed to a $0.1 \mathrm{~g}$ catalyst that had been pretreated in situ in a flow of $\mathrm{He}$ at $650^{\circ} \mathrm{C}$ for $2 \mathrm{~h}$ at a rate of $45 \mathrm{~cm}^{3} \mathrm{~min}^{-1}$. The effect of variation of $\mathrm{CH}_{4} / \mathrm{O}_{2}$ ratio was also investigated, where $\mathrm{O}_{2}$ concentration was varied over the range of 5.5-22.2\% and $\mathrm{CH}_{4}$ concentration was fixed at $44.4 \%$. The reaction temperature was increased from 650 to $800^{\circ} \mathrm{C}$ in steps of $50^{\circ} \mathrm{C}$, and the steady-state catalytic activity was measured at each temperature. The effluent gas was analyzed with the use of on-line gas chromatograph equipped with TCD and FID as a detector (Shimadzu GC-2014ATTF) using a Molecular Sieve 13X column (for analysis of $\mathrm{O}_{2}, \mathrm{CH}_{4}$, and $\mathrm{CO}$ ), a Porapak QS column (for analysis of $\mathrm{CO}_{2}$ ), and a DC-200 (20\%)/Shimalite column (for analysis of $\mathrm{C}_{2} \mathrm{H}_{4}$ and $\mathrm{C}_{2} \mathrm{H}_{6}$ ).

\section{RESULTS AND DISCUSSION}

\section{Activity of $\mathrm{CeO}_{2} / \mathrm{Y}_{2} \mathrm{O}_{3}$ Prepared by Different Method}

Figure 1A shows the XRD patterns of $3 \mathrm{~mol} \% \mathrm{CeO}_{2} / \mathrm{Y}_{2} \mathrm{O}_{3}$ prepared by different method. Distinct XRD peaks indexed to the cubic phase of $\mathrm{Y}_{2} \mathrm{O}_{3}$ were observed for all the samples. No peaks due to $\mathrm{CeO}_{2}$ were detected because of the low loading (3 mol\%), suggesting the presence of $\mathrm{CeO}_{2}$ nanoparticles. It is of interest that a shift of XRD peaks due to $\mathrm{Y}_{2} \mathrm{O}_{3}$ toward lower angle was observed for $\mathrm{CeO}_{2} / \mathrm{Y}_{2} \mathrm{O}_{3}(\mathrm{HP})$ (Figure 1B-b), suggesting the formation of $\mathrm{CeO}_{2}-\mathrm{Y}_{2} \mathrm{O}_{3}$ solid solution. This can be explained by the fact that the radius of $\mathrm{Ce}^{3+}$ ion $(0.114 \mathrm{~nm}) / \mathrm{Ce}^{4+}$ ion $(0.097 \mathrm{~nm})$ is larger than that of $\mathrm{Y}^{3+}$ ion $(0.09 \mathrm{~nm})$ (Shannon, 1976). Homogeneous precipitation including $\mathrm{Ce}^{3+}$ and $\mathrm{Y}^{3+}$ ions may be produced under the conditions, where the $\mathrm{pH}$ of solution is gradually increased via the hydrolysis of urea.

Table 1 summarizes the crystallite size of $\mathrm{Y}_{2} \mathrm{O}_{3}$, which was calculated from the XRD peak due to the (222) plane (2 $\theta$ $=29.1^{\circ}$ ) using Scherrer's equation without the subtraction of the instrument broadening, where shape factor of " $\mathrm{K}$ " was used as 0.9, and the BET surface area of $\mathrm{CeO}_{2} / \mathrm{Y}_{2} \mathrm{O}_{3}$. No significant difference in the crystallite size of $\mathrm{Y}_{2} \mathrm{O}_{3}$ was observed for $\mathrm{CeO}_{2} / \mathrm{Y}_{2} \mathrm{O}_{3}(\mathrm{CP}), \mathrm{CeO}_{2} / \mathrm{Y}_{2} \mathrm{O}_{3}(\mathrm{HP})$ and $\mathrm{CeO}_{2} / \mathrm{Y}_{2} \mathrm{O}_{3}(\mathrm{I})$. In accordance with this, these samples gave similar BET surface area in the range of $23-28 \mathrm{~m}^{2} \mathrm{~g}^{-1}$. On the other hand, the BET surface area of $\mathrm{CeO}_{2} / \mathrm{Y}_{2} \mathrm{O}_{3}(\mathrm{HT})$ was lower than those of other samples, although the crystallite size of $\mathrm{Y}_{2} \mathrm{O}_{3}$ was evaluated to be small. This conflict might be ascribed to the formation of aggregated $\mathrm{Y}_{2} \mathrm{O}_{3}$ crystallites with lessporous structure via hydrothermal process (Haneda et al., 2018).

Figure 2 shows the catalytic activity of $3 \mathrm{~mol} \% \mathrm{CeO}_{2} / \mathrm{Y}_{2} \mathrm{O}_{3}$ for the OCM reaction. It appears that the addition of $\mathrm{CeO}_{2}$ into $\mathrm{Y}_{2} \mathrm{O}_{3}$ by coprecipitation (CP), impregnation (I), and hydrothermal (HT) processes caused an increase in not only $\mathrm{CH}_{4}$ conversion (Figure 2A) but also $\mathrm{C}_{2}$ selectivity (Figure 2B) in the entire temperature range, suggesting that $\mathrm{CeO}_{2}$ is effective additive for the OCM reaction. Since the participation of oxygen species such as $\mathrm{O}^{-}, \mathrm{O}_{2}^{-}, \mathrm{O}^{2-}$, and $\mathrm{O}_{2}^{2-}$ formed on the catalyst surface in the activation of $\mathrm{CH}_{4}$ molecule for the OCM reaction has been established by many researchers (Keller and Bhasin, 1982; Borchert and Baerns, 1997; Sekine et al., 2009; Takanabe, 2012; Liang et al., 2014), active oxygen species would be efficiently supplied from the lattice of $\mathrm{CeO}_{2}$. On the other hand, as seen in Figure 2, $\mathrm{CeO}_{2} / \mathrm{Y}_{2} \mathrm{O}_{3}(\mathrm{HP})$ showed lower $\mathrm{CH}_{4}$ conversion and $\mathrm{C}_{2}$ selectivity than $\mathrm{Y}_{2} \mathrm{O}_{3}$. This is probably ascribed to the formation of $\mathrm{CeO}_{2}-\mathrm{Y}_{2} \mathrm{O}_{3}$ solid solution revealed from XRD measurements (Figure 1Bb), resulting in ineffective supply of active oxygen species. Taking into account the fact that $\mathrm{CeO}_{2} / \mathrm{Y}_{2} \mathrm{O}_{3}(\mathrm{HP})$ possesses similar physico-chemical properties, such as BET surface area and crystallite size (Table 1), with $\mathrm{CeO}_{2} / \mathrm{Y}_{2} \mathrm{O}_{3}(\mathrm{CP})$ and $\mathrm{CeO}_{2} / \mathrm{Y}_{2} \mathrm{O}_{3}(\mathrm{I})$, it is suspected the presence of the important factors affecting the catalytic activity of $\mathrm{CeO}_{2} / \mathrm{Y}_{2} \mathrm{O}_{3}$ for the OCM reaction. 



FIGURE 1 | XRD patterns of (a) $\mathrm{CeO}_{2} / \mathrm{Y}_{2} \mathrm{O}_{3}(\mathrm{CP})$, (b) $\mathrm{CeO}_{2} / \mathrm{Y}_{2} \mathrm{O}_{3}(\mathrm{HP})$, (c) $\mathrm{CeO}_{2} / \mathrm{Y}_{2} \mathrm{O}_{3}$ (l), (d) $\mathrm{CeO}_{2} / \mathrm{N}_{2} \mathrm{O}_{3}(\mathrm{HT})$ given in the wide range of $2 \theta=16-64^{\circ}$ (A) and in the expanded range of $2 \theta=28.0-30.5^{\circ}$ (B)
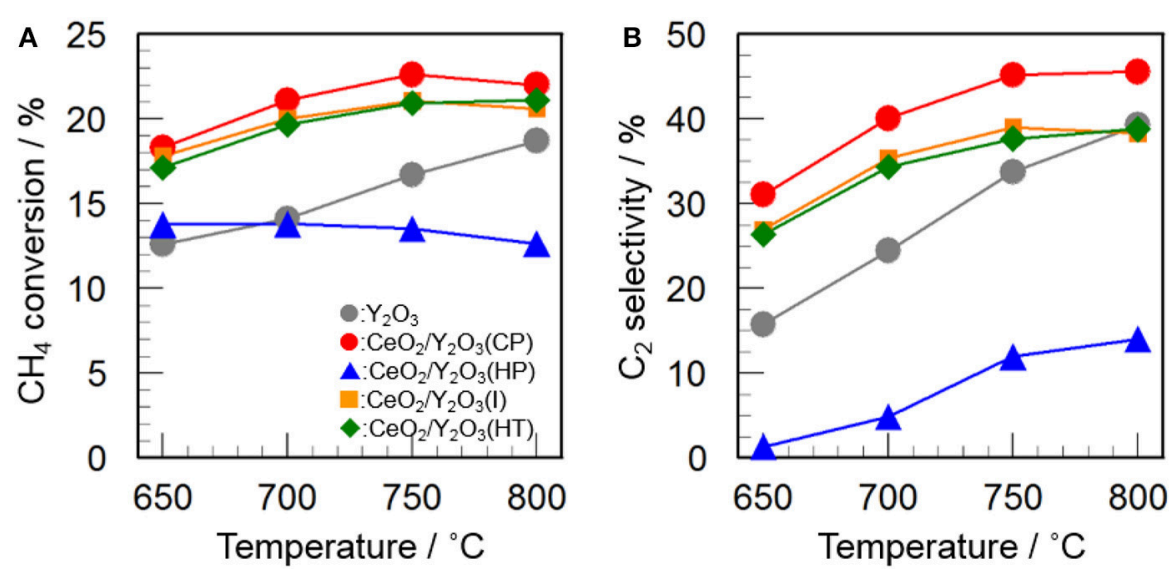

FIGURE 2 | Catalytic activity of 3 mol\% $\mathrm{CeO}_{2} / \mathrm{Y}_{2} \mathrm{O}_{3}$ for the OCM reaction. (A) $\mathrm{CH}_{4}$ conversion and (B) $\mathrm{C}_{2}$ selectivity.

\section{Effect of $\mathrm{CeO}_{2}$ Loading on the Activity of $\mathrm{CeO}_{2} / \mathrm{Y}_{2} \mathrm{O}_{3}$ (CP)}

\section{Structural Characterization of $\mathrm{CeO}_{2} / \mathrm{Y}_{2} \mathrm{O}_{3}$ (CP)}

In order to gain information on the activity controlling factor, the catalytic performance of $\mathrm{CeO}_{2}(x) / \mathrm{Y}_{2} \mathrm{O}_{3}(\mathrm{CP})$ with different $\mathrm{CeO}_{2}$ loading was examined. Structural characterizations were carried out. In Table 2 are summarized the BET surface area of $\mathrm{CeO}_{2}(x) / \mathrm{Y}_{2} \mathrm{O}_{3}(\mathrm{CP})$. It appears that no significant difference in the BET surface area was obtained in the range of $19-27 \mathrm{~m}^{2} \mathrm{~g}^{-1}$. Figure 3A shows the XRD patterns of $\mathrm{CeO}_{2}(x) / \mathrm{Y}_{2} \mathrm{O}_{3}(\mathrm{CP})$. No other peaks, except for those assignable to $\mathrm{Y}_{2} \mathrm{O}_{3}$, were detected irrespective of $\mathrm{CeO}_{2}$ loading. It is also noteworthy that a shift of XRD peaks by the addition of $\mathrm{CeO}_{2}$ was not recognized. Figure 3B shows the Raman spectra of $\mathrm{CeO}_{2}(x) / \mathrm{Y}_{2} \mathrm{O}_{3}(\mathrm{CP})$.
Raman bands ascribed to $F_{g}+A_{g}$ mode of cubic $\mathrm{Y}_{2} \mathrm{O}_{3}$ with Ctype structure (Repelin et al., 1995; Yashima et al., 1997; Ubaldini and Carnasciali, 2008) were observed for all the samples, and their intensities were gradually decreased with an increase in $\mathrm{CeO}_{2}$ loading. From XRD and Raman measurements, $\mathrm{CeO}_{2}$ particles were revealed to present as highly dispersion state on the surface and/or in the bulk of $\mathrm{Y}_{2} \mathrm{O}_{3}$.

In order to gain information on the dispersion state of $\mathrm{CeO}_{2}$ particles, the morphology of $\mathrm{CeO}_{2}(x) / \mathrm{Y}_{2} \mathrm{O}_{3}(\mathrm{CP})$ with the $\mathrm{CeO}_{2}$ loadings $(x)$ of 0,3 , and $10 \mathrm{~mol} \%$ was observed by TEM analysis. As can be seen in Figures $4 \mathbf{a}-\mathbf{c}$, the addition of $\mathrm{CeO}_{2}$ into $\mathrm{Y}_{2} \mathrm{O}_{3}$ did not cause a significant change in the particle morphology, whereas the particle size was gradually decreased. This is in accordance with the crystallite size of $\mathrm{Y}_{2} \mathrm{O}_{3}$ 

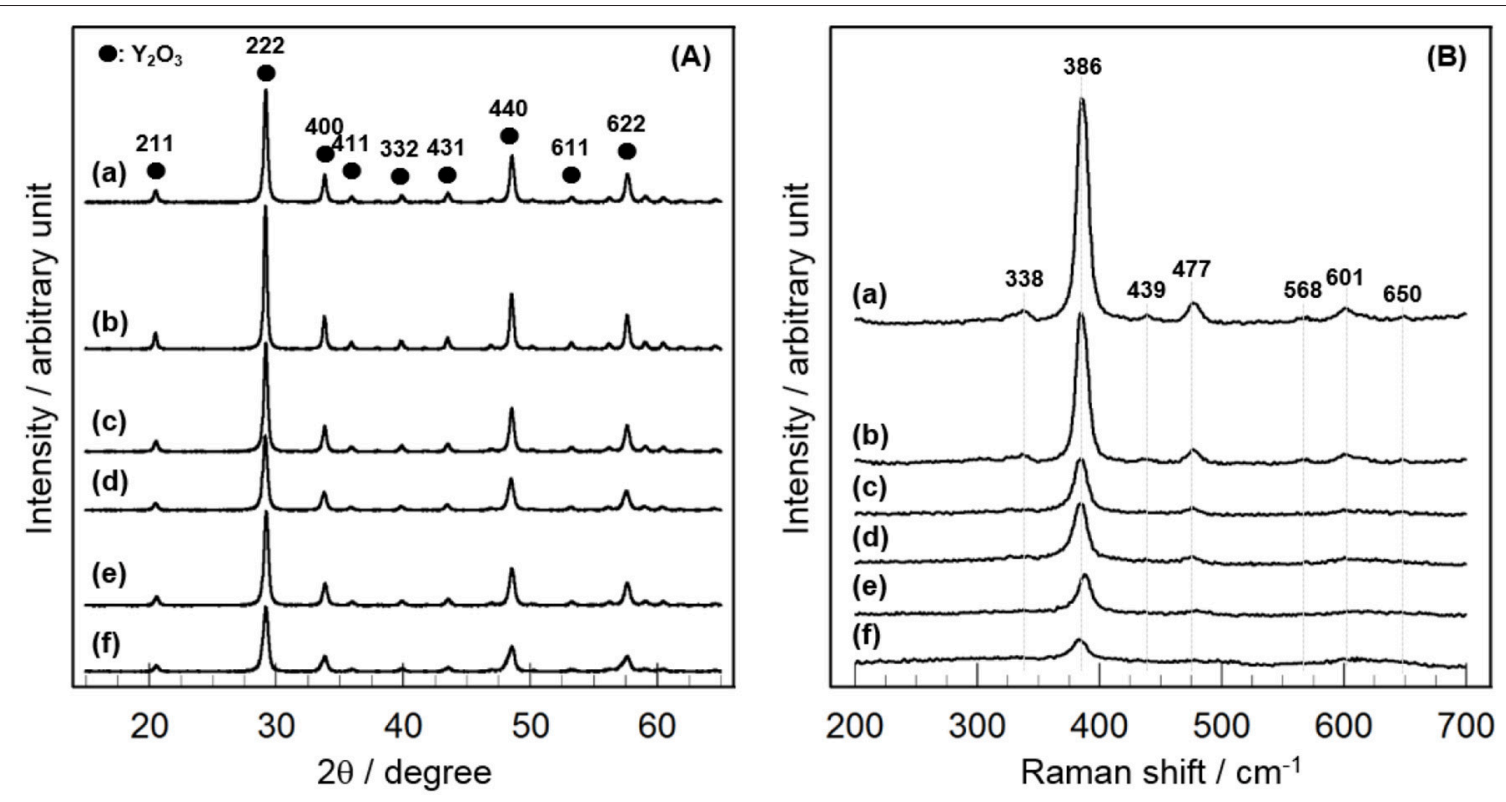

FIGURE 3 | Structural characterization of $\mathrm{CeO}_{2}(x) / \mathrm{Y}_{2} \mathrm{O}_{3}(\mathrm{CP})$ by (A) $X R D$ and (B) Raman. (a) $\mathrm{Y}_{2} \mathrm{O}_{3},(\mathrm{~b}) \mathrm{CeO}_{2}(1) / \mathrm{Y}_{2} \mathrm{O}_{3}(\mathrm{CP}),(\mathrm{c}) \mathrm{CeO} 2(3) / \mathrm{Y}_{2} \mathrm{O}_{3}(\mathrm{CP}),(\mathrm{d})$ $\mathrm{CeO}_{2}(4) / \mathrm{Y}_{2} \mathrm{O}_{3}(\mathrm{CP})$, (e) $\mathrm{CeO}_{2}(5) / \mathrm{Y}_{2} \mathrm{O}_{3}(\mathrm{CP})$, (f) $\mathrm{CeO}_{2}(10) / \mathrm{Y}_{2} \mathrm{O}_{3}(\mathrm{CP})$.

(Table 2). These results suggest that the aggregated particles observed in TEM images mainly consist of $\mathrm{Y}_{2} \mathrm{O}_{3}$. Figures $4 \mathbf{d}-\mathbf{f}$ show the TEM images of $\mathrm{CeO}_{2}(x) / \mathrm{Y}_{2} \mathrm{O}_{3}(\mathrm{CP})$ observed at high magnification. Unfortunately, $\mathrm{CeO}_{2}$ and $\mathrm{Y}_{2} \mathrm{O}_{3}$ particles were not clearly distinguished each other because of low $\mathrm{CeO}_{2}$ loading $(<10 \mathrm{~mol} \%)$ and the same crystal system (cubic). However, it appears from the comparison of Figures 4d,e that the surface morphology of $\mathrm{Y}_{2} \mathrm{O}_{3}$ was changed by addition of $3 \mathrm{~mol} \%$ $\mathrm{CeO}_{2}$. Namely, $\mathrm{Y}_{2} \mathrm{O}_{3}$ consists of the particles with smooth surface (Figure 4d), whereas the surface of $\mathrm{Y}_{2} \mathrm{O}_{3}$ particles in $\mathrm{CeO}_{2}(3) / \mathrm{Y}_{2} \mathrm{O}_{3}(\mathrm{CP})$ seems to be rough (Figure 4e), suggesting the surface interaction between $\mathrm{CeO}_{2}$ and $\mathrm{Y}_{2} \mathrm{O}_{3}$. In other words, $\mathrm{CeO}_{2}$ nanoparticles of which the size is smaller than the detection limit by TEM and XRD might be dispersed on the surface of $\mathrm{Y}_{2} \mathrm{O}_{3}$ particles. On the other hand, as seen in Figure 4f, $\mathrm{CeO}_{2}(10) / \mathrm{Y}_{2} \mathrm{O}_{3}(\mathrm{CP})$ seems to be composed of a plurality of particles with different surface morphology. $\mathrm{CeO}_{2}$ nanoparticles might be present not only independently but also weakly interacting with $\mathrm{Y}_{2} \mathrm{O}_{3}$.

\section{Catalytic Activity of $\mathrm{CeO}_{2} / \mathrm{Y}_{2} \mathrm{O}_{3}(\mathrm{CP})$ for the OCM Reaction}

Figure 5 shows the effect of $\mathrm{CeO}_{2}$ loading on the catalytic activity of $\mathrm{CeO}_{2}(x) / \mathrm{Y}_{2} \mathrm{O}_{3}(\mathrm{CP})$ for the OCM reaction. As mentioned before, the addition of $\mathrm{CeO}_{2}$ into $\mathrm{Y}_{2} \mathrm{O}_{3}$ caused an increase in not only $\mathrm{CH}_{4}$ conversion but also $\mathrm{C}_{2}$ selectivity in the entire temperature range. As can be seen in Figure $\mathbf{5} \mathbf{A}, \mathrm{CH}_{4}$ conversion was drastically increased by addition of $3 \mathrm{~mol} \%$ $\mathrm{CeO}_{2}$. Further increase in $\mathrm{CeO}_{2}$ loading up to $10 \mathrm{~mol} \%$ did not cause any change in the $\mathrm{CH}_{4}$ conversion. In accordance with previous reports (Primet and Garbowski, 2002), $\mathrm{CeO}_{2}$ seems to be good additive for the activation of $\mathrm{CH}_{4}$ molecules. On the other hand, as seen in Figure 5B, the effect of $\mathrm{CeO}_{2}$ loading on the $\mathrm{C}_{2}$ selectivity was slightly different from that on the $\mathrm{CH}_{4}$ conversion. The $\mathrm{C}_{2}$ selectivity was gradually increased with an increase in the $\mathrm{CeO}_{2}$ loading up. The maximum $\mathrm{C}_{2}$ selectivity was achieved at $3 \mathrm{~mol} \% \mathrm{CeO}_{2}$ loading. However, further increase in $\mathrm{CeO}_{2}$ loading caused a gradual decrease in the $\mathrm{C}_{2}$ selectivity. The optimum $\mathrm{CeO}_{2}$ loading for the formation of $\mathrm{C}_{2} \mathrm{H}_{6} / \mathrm{C}_{2} \mathrm{H}_{4}$ as a product was found to be $3 \mathrm{~mol} \%$. As seen in Table 2, the highest BET surface area was obtained for $\mathrm{CeO}_{2}(3) / \mathrm{Y}_{2} \mathrm{O}_{3}(\mathrm{CP})$. This is in agreement with the catalytic activity. However, although $\mathrm{CeO}_{2}(5) / \mathrm{Y}_{2} \mathrm{O}_{3}(\mathrm{CP})$ was found to possess similar BET surface area with $\mathrm{CeO}_{2}(3) / \mathrm{Y}_{2} \mathrm{O}_{3}(\mathrm{CP})$, the former catalytic activity was clearly lower than that of the latter catalyst. This suggests that the BET surface area is not only the important factor to determine the catalytic activity.

Since the $\mathrm{CH}_{4} / \mathrm{O}_{2}$ ratio is an important parameter to optimize the reaction conditions, the effect of $\mathrm{CH}_{4} / \mathrm{O}_{2}$ ratio on the catalytic activity of $\mathrm{CeO}_{2}(3) / \mathrm{Y}_{2} \mathrm{O}_{3}(\mathrm{CP})$ was examined. As can be seen in Figure 6, an increase in the $\mathrm{CH}_{4} / \mathrm{O}_{2}$ ratio caused a decrease in the $\mathrm{CH}_{4}$ conversion as well as an increase in the $\mathrm{C}_{2}$ selectivity. This indicates that the reaction gas containing higher concentration of $\mathrm{O}_{2}$ is favored for the activation of $\mathrm{CH}_{4}$, resulting in high $\mathrm{CH}_{4}$ conversion, while is also favored for the formation of undesirable $\mathrm{CO}_{2}$, leading to low $\mathrm{C}_{2}$ selectivity. The trade-off between $\mathrm{CH}_{4}$ conversion and $\mathrm{C}_{2}$ selectivity is well-known phenomena in the OCM reaction (Ghose et al., 2014; Godini et al., 2014; Ivanov et al., 2014). From the kinetic point of view, the activated $\mathrm{CH}_{4}$ molecule $\left(\mathrm{CH}_{3}\right.$. radical) may preferentially react with $\mathrm{O}_{2}$ species in the presence of excess $\mathrm{O}_{2}$. It would be important to explore the optimum reaction conditions to achieve high $\mathrm{C}_{2}$ productivity. 

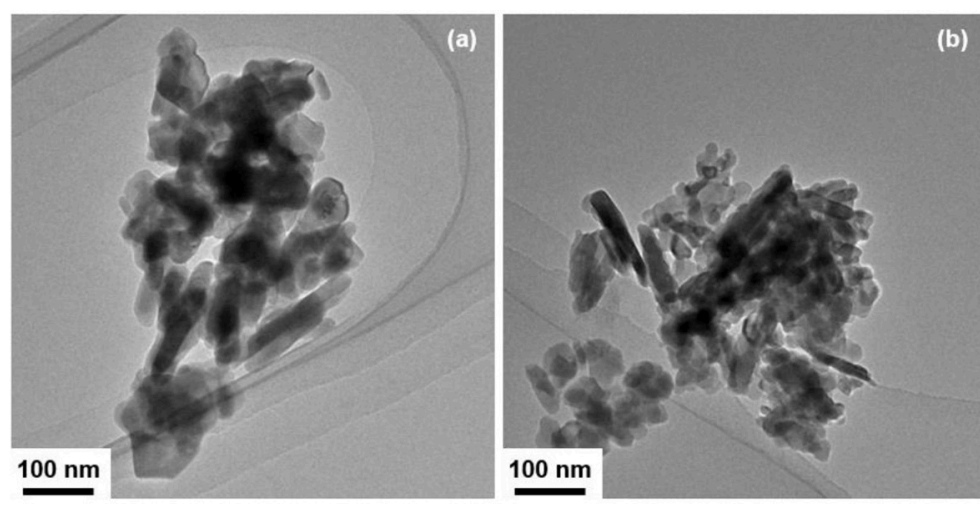

(b)
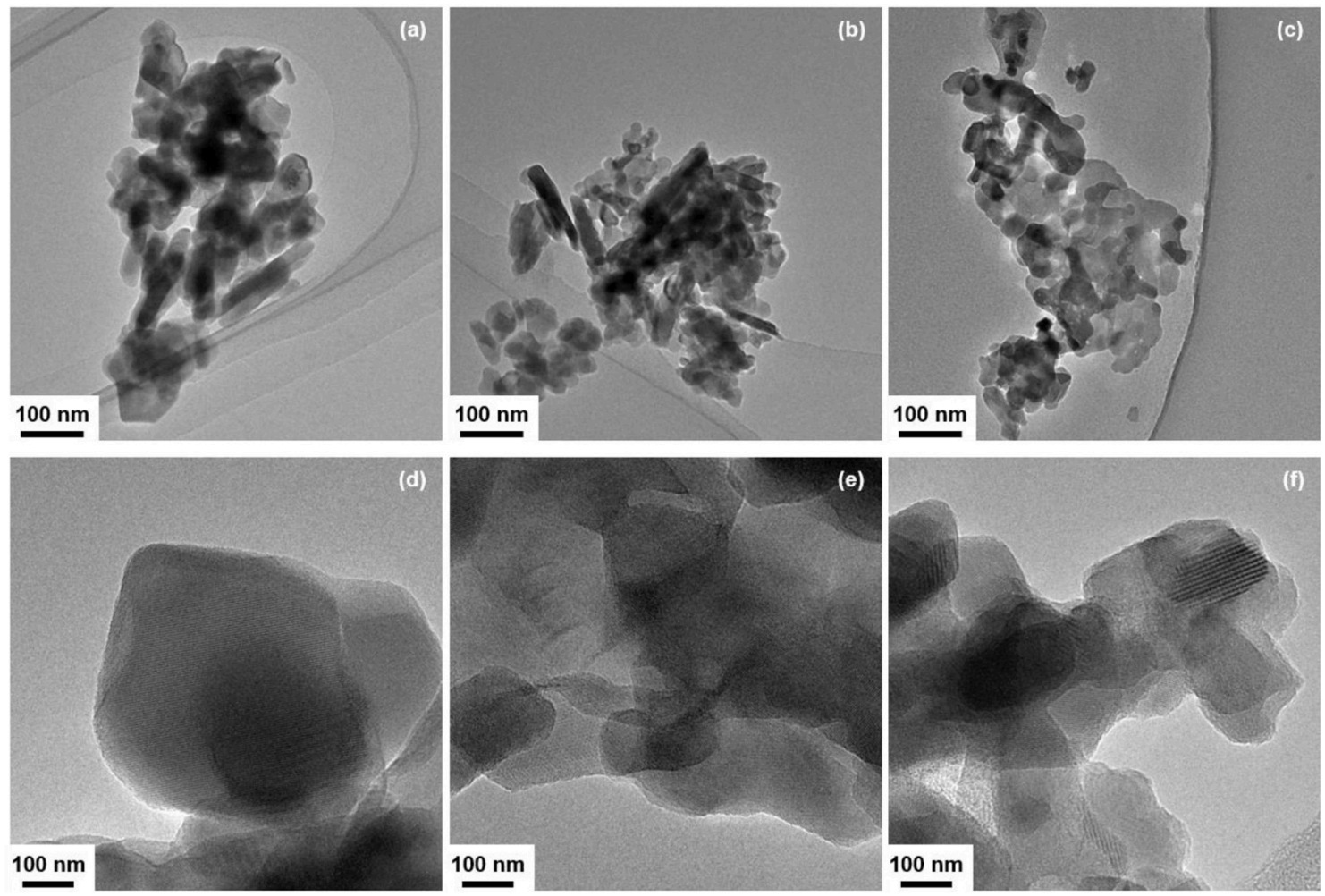

FIGURE 4 | TEM images of (a,d) $\mathrm{Y}_{2} \mathrm{O}_{3}$, (b,e) $\mathrm{CeO}_{2}(3) / \mathrm{Y}_{2} \mathrm{O}_{3}(\mathrm{CP}),(\mathbf{c}, \mathbf{f}) \mathrm{CeO}_{2}(10) / \mathrm{Y}_{2} \mathrm{O}_{3}(\mathrm{CP})$.

TABLE 2 | BET surface area, crystallite size of $\mathrm{Y}_{2} \mathrm{O}_{3}$ and the amount of $\mathrm{H}_{2}$ consumption in $\mathrm{H}_{2}$-TPR of $\mathrm{CeO}_{2}(x) / \mathrm{Y}_{2} \mathrm{O}_{3}$ (CP).

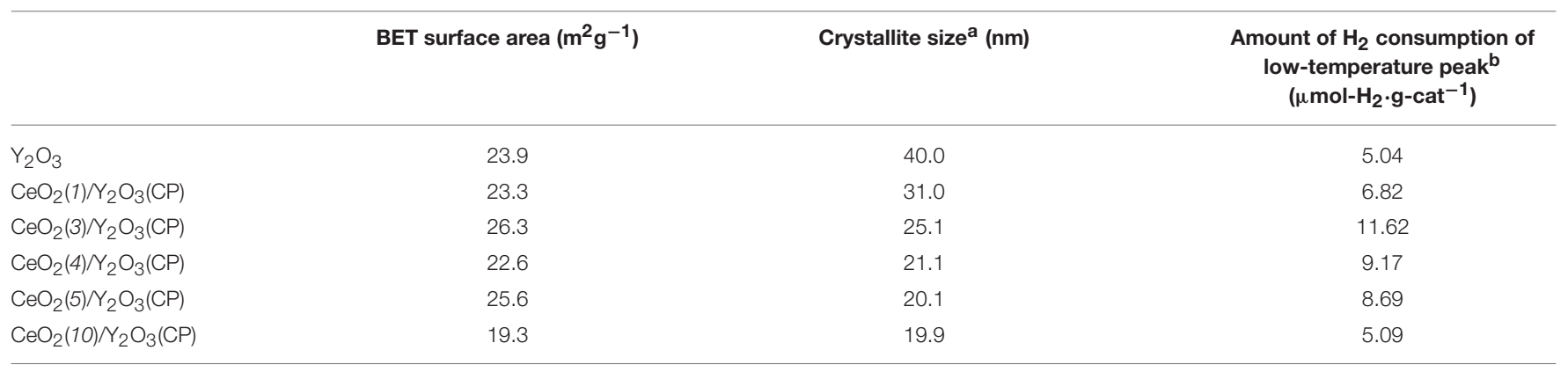

a The crystallite size of $\mathrm{Y}_{2} \mathrm{O}_{3}$ was calculated from the XRD peak, given in Figure 1, from the (222) plane using Scherrer's equation.

${ }^{b}$ The amount of $\mathrm{H}_{2}$ consumption for the reduction of surface/subsurface oxygen species in the temperature range of $100-400^{\circ} \mathrm{C}$, given in Figure 7 , was estimated.

\section{Active Sites for the OCM Reaction Over $\mathrm{CeO}_{2} / \mathrm{Y}_{2} \mathrm{O}_{3}$ (CP)}

$\mathrm{XRD}$ and Raman measurements revealed that $\mathrm{CeO}_{2}$ particles are present as highly dispersion state on the surface and/or in the bulk of $\mathrm{Y}_{2} \mathrm{O}_{3}$ (Figure 3). In addition, TEM observation suggested that the dispersion state of $\mathrm{CeO}_{2}$ particles is different depending on $\mathrm{CeO}_{2}$ loading (Figure 4). In case of $\mathrm{CeO}_{2}(3) / \mathrm{Y}_{2} \mathrm{O}_{3}(\mathrm{CP}), \mathrm{CeO}_{2}$ nanoparticles might be dispersed on the surface of $\mathrm{Y}_{2} \mathrm{O}_{3}$ particles, while $\mathrm{CeO}_{2}$ nanoparticles might be present not only independently but also weakly interacting with $\mathrm{Y}_{2} \mathrm{O}_{3}$ in $\mathrm{CeO}_{2}(10) / \mathrm{Y}_{2} \mathrm{O}_{3}(\mathrm{CP})$. Therefore, the dispersion state of $\mathrm{CeO}_{2}$ would be related to the catalytic activity. It is well known that the reduction of $\mathrm{CeO}_{2}$ particles gradually proceeds from surface to bulk in the wide range from low to high temperature region, respectively (Yao and Yao, 1984; Trovarelli, 1996; Imagawa et al., 2011). In order to obtain an information on the dispersion state of $\mathrm{CeO}_{2}, \mathrm{H}_{2}-\mathrm{TPR}$ measurements were carried out. As given in Figure 7a, very broad $\mathrm{H}_{2}$ consumption peaks in the temperature range of 100$700^{\circ} \mathrm{C}$ were observed in the $\mathrm{H}_{2}$-TPR profile of $\mathrm{Y}_{2} \mathrm{O}_{3}$. This is probably due to the reduction of oxygen species interacting with the defects sites in the lattice of $\mathrm{Y}_{2} \mathrm{O}_{3}$ with $\mathrm{C}$-type structure. No significant change in the $\mathrm{H}_{2}$-TPR profile was observed for $\mathrm{CeO}_{2}(1) / \mathrm{Y}_{2} \mathrm{O}_{3}(\mathrm{CP})$ (Figure 7b). This is in agreement with the 

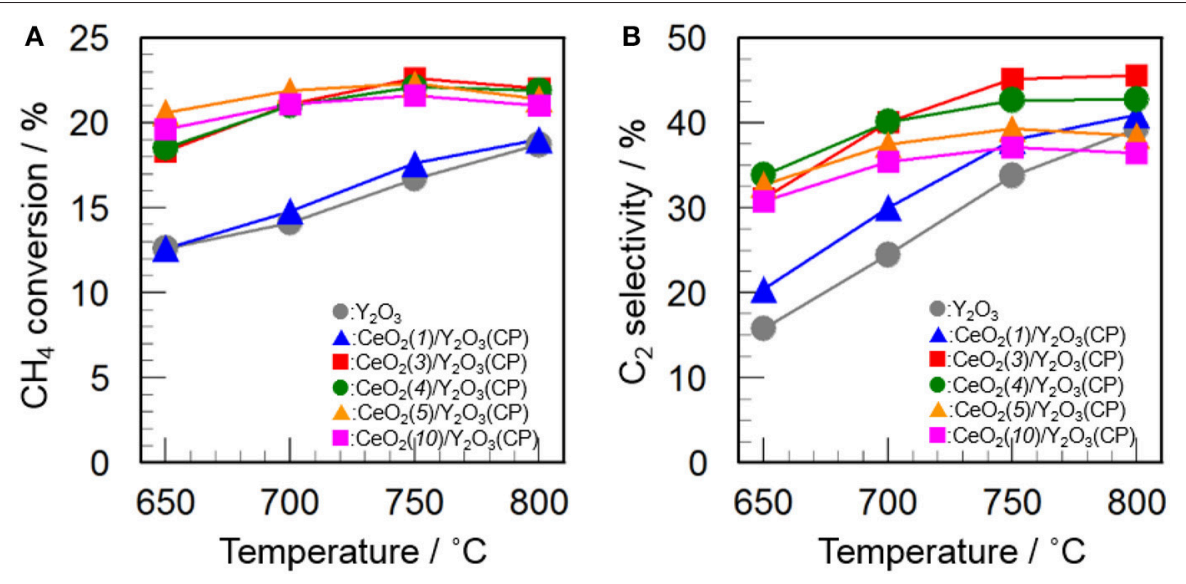

FIGURE 5 | Effect of $\mathrm{CeO}_{2}$ loading on the activity of $\mathrm{CeO}_{2}(x) / \mathrm{Y}_{2} \mathrm{O}_{3}(\mathrm{CP})$ for the OCM reaction. (A) $\mathrm{CH}_{4}$ conversion and (B) $\mathrm{C}_{2}$ selectivity.


FIGURE 6 | Effect of $\mathrm{CH}_{4} / \mathrm{O}_{2}$ ratio on $\mathbf{( A )} \mathrm{CH}_{4}$ conversion and (B) $\mathrm{C}_{2}$ selectivity in the $\mathrm{OCM}$ reaction over $\mathrm{CeO}_{2}(3) / \mathrm{Y}_{2} \mathrm{O}_{3}(\mathrm{CP})$. (Red circles) $\mathrm{CH} / \mathrm{O}_{2}=2$, (blue triangles) $\mathrm{CH}_{4} / \mathrm{O}_{2}=4$, (green squares) $\mathrm{CH}_{4} / \mathrm{O}_{2}=8$.

tendency of the catalytic activity (Figure 5). It is noteworthy that the addition of $3 \mathrm{~mol} \% \mathrm{CeO}_{2}$ caused an appearance of distinct $\mathrm{H}_{2}$ consumption peaks at around 200 and $600^{\circ} \mathrm{C}$ (Figure 7c). The area of $\mathrm{H}_{2}$ consumption peak at around $600^{\circ} \mathrm{C}$, which can be ascribed to the reduction of oxygen species in the bulk of $\mathrm{CeO}_{2}$ (Yao and Yao, 1984; Trovarelli, 1996; Imagawa et al., 2011), was gradually increased with an increase in $\mathrm{CeO}_{2}$ loading up to $10 \mathrm{~mol} \%$. In contrast, the lowtemperature peak at around $200{ }^{\circ} \mathrm{C}$ due to the reduction of surface/subsurface oxygen species on $\mathrm{CeO}_{2}$ particles (Yao and Yao, 1984; Trovarelli, 1996; Imagawa et al., 2011) was clearly decreased for $\mathrm{CeO}_{2}(10) / \mathrm{Y}_{2} \mathrm{O}_{3}(\mathrm{CP})$. These results suggest that the size of $\mathrm{CeO}_{2}$ particles dispersed on the surface and/or in the bulk of $\mathrm{Y}_{2} \mathrm{O}_{3}$ was significantly increased with an increase in $\mathrm{CeO}_{2}$ loading.

Table 2 summarizes the amount of $\mathrm{H}_{2}$ consumption for the reduction of surface/subsurface oxygen species in the temperature range of $100-400^{\circ} \mathrm{C}$. It is of interest that the maximum amount of $\mathrm{H}_{2}$ consumption was obtained for $\mathrm{CeO}_{2}(3) / \mathrm{Y}_{2} \mathrm{O}_{3}(\mathrm{CP})$, and then decreased with $\mathrm{CeO}_{2}$ loading. Figure 8 shows the relationship between the amount of $\mathrm{H}_{2}$ consumption for the reduction of surface/subsurface oxygen species and the catalytic activity for the OCM reaction at $750{ }^{\circ} \mathrm{C}$. It appears that the $\mathrm{CH}_{4}$ conversion and $\mathrm{C}_{2}$ selectivity were linearly increased with an increase in the amount of $\mathrm{H}_{2}$ consumption. This clearly indicates that oxygen species on the surface/subsurface of highly dispersed $\mathrm{CeO}_{2}$ particles can effectively activate $\mathrm{CH}_{4}$ molecule, resulting in the selective formation of $\mathrm{C}_{2} \mathrm{H}_{6} / \mathrm{C}_{2} \mathrm{H}_{4}$. On the basis of XRD, Raman, TEM, and $\mathrm{H}_{2}$-TPR measurements, we can conclude that the creation of highly dispersed $\mathrm{CeO}_{2}$ particles is one of the strategies for the catalyst design leading to the development of highly active OCM catalysts. 


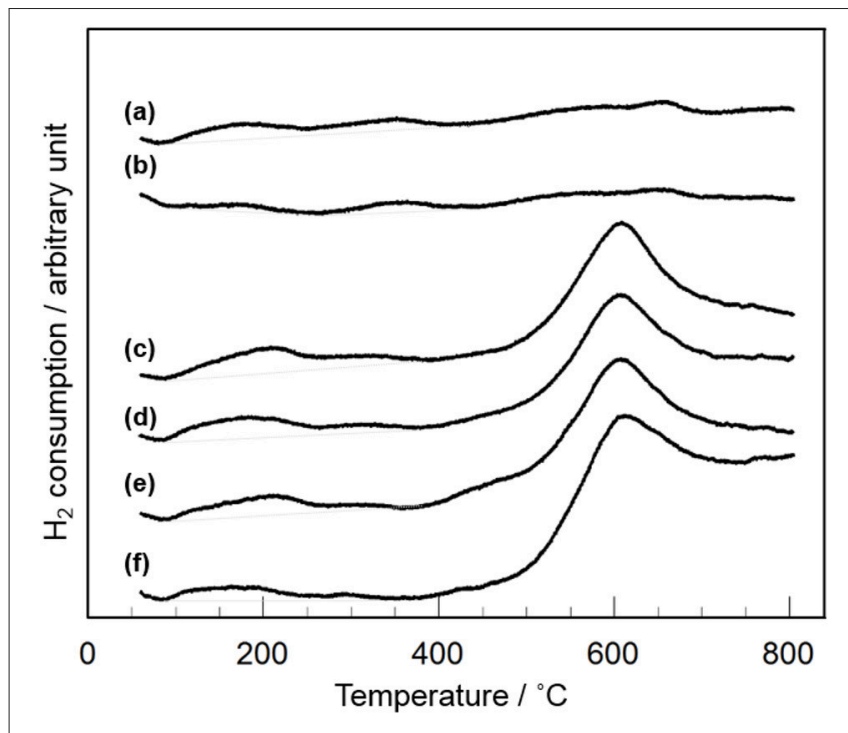

FIGURE $7 \mid \mathrm{H}_{2}$-TPR profiles of $\mathrm{CeO}_{2}(x) / \mathrm{Y}_{2} \mathrm{O}_{3}(\mathrm{CP})$ with different $\mathrm{CeO}_{2}$ loading. (a) $\mathrm{Y}_{2} \mathrm{O}_{3}$, (b) $\mathrm{CeO}_{2}(1) / \mathrm{Y}_{2} \mathrm{O}_{3}$ (CP), (c) $\mathrm{CeO}_{2}(3) / \mathrm{Y}_{2} \mathrm{O}_{3}$ (CP), (d) $\mathrm{CeO}_{2}(4) / \mathrm{Y}_{2} \mathrm{O}_{3}(\mathrm{CP})$, (e) $\mathrm{CeO}_{2}(5) / \mathrm{Y}_{2} \mathrm{O}_{3}(\mathrm{CP})$, (f) $\mathrm{CeO}_{2}(10) / \mathrm{Y}_{2} \mathrm{O}_{3}$ (CP).

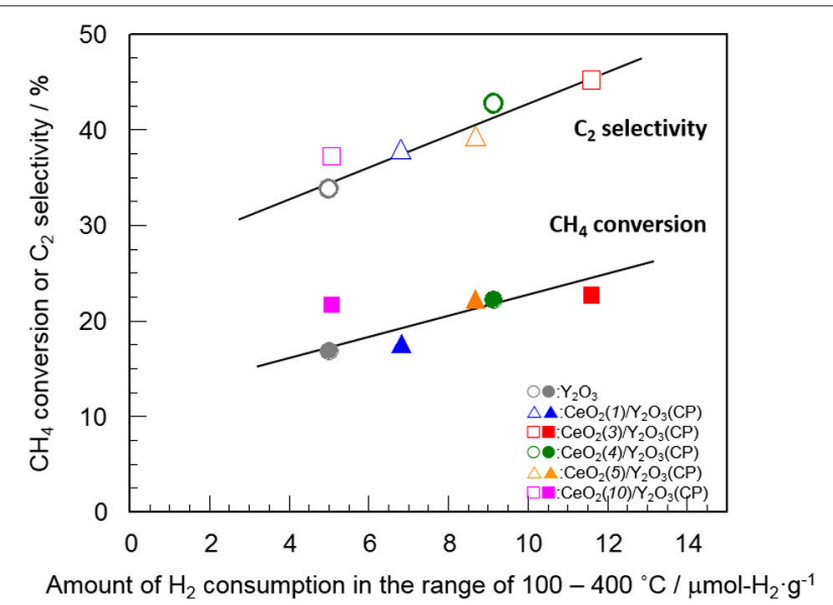

FIGURE 8 | Relationship between the amount of $\mathrm{H}_{2}$ consumption for the reduction of surface/subsurface oxygen species and the catalytic activity for the $\mathrm{OCM}$ reaction at $750^{\circ} \mathrm{C}$.

\section{Catalytic Role of $\mathrm{CeO}_{2}$ in the OCM Reaction}

Since $\mathrm{CeO}_{2}$ is well-known material showing reversible oxygen release/absorb properties (Trovarelli, 1996), the ${ }^{16} \mathrm{O} /{ }^{18} \mathrm{O}$ isotopic exchange reaction was carried out to clarify the possibility of $\mathrm{O}_{2}$ activation as catalytically role of $\mathrm{CeO}_{2}$ in the OCM reaction. Martin and Duprez (1996) and Duprez (2006) investigated the oxygen mobility of various kinds of oxide by using the ${ }^{16} \mathrm{O} /{ }^{18} \mathrm{O}$ isotopic exchange reaction, and proposed two mechanisms depending on the type of oxide. One group is non-reducible oxide such as $\mathrm{Al}_{2} \mathrm{O}_{3}, \mathrm{SiO}_{2}, \mathrm{ZrO}_{2}$ and $\mathrm{MgO}$, and the other is reducible oxide such as $\mathrm{CeO}_{2}$ and $\mathrm{CeO}_{2}-\mathrm{ZrO}_{2}$. In the former case, the simple hetero-exchange that occurs with the participation of only one oxygen of the oxide at each step of the following equations (1) and (2):

$$
\begin{aligned}
& { }^{18} \mathrm{O}_{2}(\mathrm{~g})+{ }^{16} \mathrm{O}(\mathrm{s}) \rightarrow{ }^{18} \mathrm{O}^{16} \mathrm{O}(\mathrm{g})+{ }^{18} \mathrm{O}(\mathrm{s}) \\
& { }^{18} \mathrm{O}^{16} \mathrm{O}(\mathrm{g})+{ }^{16} \mathrm{O}(\mathrm{s}) \rightarrow{ }^{16} \mathrm{O}_{2}(\mathrm{~g})+{ }^{18} \mathrm{O}(\mathrm{s})
\end{aligned}
$$

Here, the consecutive evolution of ${ }^{18} \mathrm{O}^{16} \mathrm{O}$ and ${ }^{16} \mathrm{O}_{2}$ can be observed. On the other hand, the isotopic exchange reaction over reducible oxides takes place via the multiple-hetero exchange mechanism, where the reaction between a molecule dioxygen $\left({ }^{18} \mathrm{O}_{2}\right)$ in gas phase and two atomic oxygens $\left({ }^{16} \mathrm{O}\right)$ of the solid occurs the following equation (3) or (4):

$$
\begin{aligned}
& { }^{18} \mathrm{O}_{2}(\mathrm{~g})+2{ }^{16} \mathrm{O}(\mathrm{s}) \rightarrow{ }^{18} \mathrm{O}^{16} \mathrm{O}(\mathrm{g})+{ }^{18} \mathrm{O}(\mathrm{s})+{ }^{16} \mathrm{O}(\mathrm{s}) \\
& { }^{18} \mathrm{O}_{2}(\mathrm{~g})+2{ }^{16} \mathrm{O}(\mathrm{s}) \rightarrow{ }^{16} \mathrm{O}_{2}(\mathrm{~g})+2{ }^{18} \mathrm{O}(\mathrm{s})
\end{aligned}
$$

In this case, ${ }^{16} \mathrm{O}_{2}$ and ${ }^{16} \mathrm{O}^{18} \mathrm{O}$ seem to be simultaneously evolved.

Figure 9 shows the profiles of ${ }^{16} \mathrm{O}_{2}$ and ${ }^{16} \mathrm{O}^{18} \mathrm{O}$ evolution and ${ }^{18} \mathrm{O}_{2}$ consumption in the ${ }^{16} \mathrm{O} /{ }^{18} \mathrm{O}$ isotopic exchange reaction over $\mathrm{Y}_{2} \mathrm{O}_{3}$ and $\mathrm{CeO}_{2}(3) / \mathrm{Y}_{2} \mathrm{O}_{3}(\mathrm{CP})$. It appears that both catalysts gave similar profiles for each $\mathrm{O}_{2}$ species. The evolution of ${ }^{16} \mathrm{O}^{18} \mathrm{O}$ and the consumption of ${ }^{18} \mathrm{O}_{2}$ were simultaneously observed, followed by the ${ }^{16} \mathrm{O}_{2}$ evolution at higher temperature. This suggests that the simple hetero-exchange mechanism is favored on $\mathrm{Y}_{2} \mathrm{O}_{3}$ and $\mathrm{CeO}_{2} / \mathrm{Y}_{2} \mathrm{O}_{3}$ with lower $\mathrm{CeO}_{2}$ loading, although the $\mathrm{O}_{2}$ activation over $\mathrm{CeO}_{2}$-containing sample was suspected to be governed by the multiple-hetero exchange mechanism. This is probably due to the high dispersion state of $\mathrm{CeO}_{2}$ nanoparticles on the surface of $\mathrm{Y}_{2} \mathrm{O}_{3}$, as revealed by $\mathrm{H}_{2}$-TPR measurement (Figure 7).

Dong et al. (2004a,b) investigated the oxygen mobility of $\mathrm{CeO}_{2}-\mathrm{ZrO}_{2}$ based catalyst with different structural homogeneity, and reported that oxygen species activated at lower temperature via the multiple-hetero exchange mechanism is highly active for the complete oxidation reaction. It can be expected that oxygen species with moderate activity, which was evolved via the simple hetero-exchange mechanism, plays a beneficial role in $\mathrm{CH}_{4}$ activation (Kumar et al., 2016), leading to the selective oxidation to $\mathrm{C}_{2} \mathrm{H}_{6} / \mathrm{C}_{2} \mathrm{H}_{4}$. Taking into account the fact that the temperature for the evolution of ${ }^{16} \mathrm{O}^{18} \mathrm{O}$ and ${ }^{16} \mathrm{O}_{2}$ was significantly lowered by addition of $\mathrm{CeO}_{2}$ into $\mathrm{Y}_{2} \mathrm{O}_{3}$ (Figure 9), we can conclude that the catalytically role of $\mathrm{CeO}_{2}$ in the OCM reaction is to promote the formation of active oxygen species via the simple hetero-exchange mechanism.

\section{CONCLUSION}

The catalytic activity of $\mathrm{Y}_{2} \mathrm{O}_{3}$ for the OCM reaction was effectively improved by addition of $\mathrm{CeO}_{2}$. Among the catalysts tested here, $\mathrm{CeO}_{2} / \mathrm{Y}_{2} \mathrm{O}_{3}$ prepared by coprecipitation method showed the highest activity. The optimum $\mathrm{CeO}_{2}$ loading was $3 \mathrm{~mol} \%$. From the structural characterizations by XRD, Raman and TEM, $\mathrm{CeO}_{2}$ particles were found to be dispersed on the 

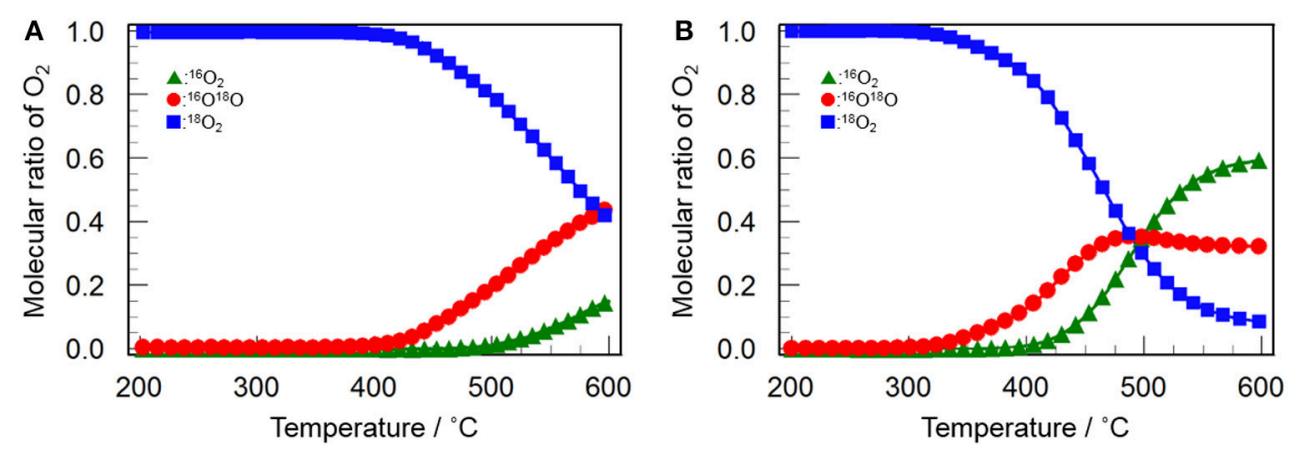

FIGURE 9 | Change in the molecular ratio of ${ }^{16} \mathrm{O}_{2}$ (green triangles), ${ }^{16} \mathrm{O}^{18} \mathrm{O}$ (red circles) and ${ }^{18} \mathrm{O}_{2}$ (blue squares) during the isotopic exchange reaction of $\mathrm{O}_{2}$ over (A) $\mathrm{Y}_{2} \mathrm{O}_{3}$ and (B) $\mathrm{CeO}_{2}(3) / \mathrm{Y}_{2} \mathrm{O}_{3}(\mathrm{CP})$ as a function of temperature.

surface of $\mathrm{Y}_{2} \mathrm{O}_{3}$ without the formation of $\mathrm{CeO}_{2}-\mathrm{Y}_{2} \mathrm{O}_{3}$ solid solution. $\mathrm{H}_{2}$-TPR measurements revealed that the amount of $\mathrm{H}_{2}$ consumption for the reduction of $\mathrm{CeO}_{2}$ surface was increased with an increase in $\mathrm{CeO}_{2}$ loading and then reached the maximum at $3 \mathrm{~mol} \%$. Highly dispersed $\mathrm{CeO}_{2}$ particles was suspected to act as catalytically active sites in the OCM reaction. From the ${ }^{16} \mathrm{O} /{ }^{18} \mathrm{O}$ isotopic exchange reaction, the beneficial role of $\mathrm{CeO}_{2}$ in the OCM reaction was concluded to promote the formation of active oxygen species via the simple hetero-exchange mechanism.

\section{REFERENCES}

Arndt, S., Laugel, G., Levchenko, S., Horn, R., Baerns, M., Scheffler, M., et al. (2011). A critical assessment of Li/MgO-based catalysts for the oxidative coupling of methane. Catal. Rev. Sci. Eng. 53, 424-514. doi: 10.1080/01614940.2011.613330

Borchert, H., and Baerns, M. (1997). The effect of oxygen-anion conductivity of metal-oxide doped lanthanum oxide catalysts on hydrocarbon selectivity in the oxidative coupling of methane. J. Catal. 168, 315-320. doi: 10.1006/jcat.1997.1662

Doi, Y., Haneda, M., and Ozawa, M. (2015). Promoting effect of $\mathrm{CeO}_{2}$ on the catalytic activity of $\mathrm{Ba}-\mathrm{Y}_{2} \mathrm{O}_{3}$ for direct decomposition of NO. Bull. Chem. Soc. Jpn. 88, 117-123. doi: 10.1246/bcsj.2014 0230

Dong, F., Suda, A., Tanabe, T., Nagai, Y., Sobukawa, H., Shinjoh, H., et al. (2004a). Characterization of the dynamic oxygen migration over $\mathrm{Pt} / \mathrm{CeO}_{2}$ $\mathrm{ZrO}_{2}$ catalysts by ${ }^{18} \mathrm{O} /{ }^{16} \mathrm{O}$ isotopic exchange reaction. Catal. Today 90 , 223-229. doi: 10.1016/j.cattod.2004.04.030

Dong, F., Suda, A., Tanabe, T., Nagai, Y., Sobukawa, H., Shinjoh, H., et al. (2004b). Dynamic oxygen mobility and a new insight into the role of $\mathrm{Zr}$ atoms in three-way catalysts of $\mathrm{Pt} / \mathrm{CeO}_{2}-\mathrm{ZrO}_{2}$. Catal. Today $93-95,827-832$. doi: $10.1016 /$ j.cattod.2004.06.076

Dubois, J. L., and Cameron, C. J. (1990). Common features of oxidative coupling of methane cofeed catalysts. Appl. Catal. 67, 49-71. doi: $10.1016 / \mathrm{S} 0166-9834(00) 84431-0$

Duprez, D. (2006). "Oxygen and hydrogen surface mobility in supported metal catalysts study by ${ }^{18} \mathrm{O} /{ }^{16} \mathrm{O}$ and ${ }^{2} \mathrm{H} /{ }^{1} \mathrm{H}$ exchange", in Isotopes in Heterogeneous Catalysis, eds J. S. J. Hargreaves, S. D. Jackson, and G. Webb (London: Imperial College Press), 133-182.

Elkins, T. W., Roberts, S. J., and Hagelin-Weaver, H. E. (2016). Effects of alkali and alkaline-earth metal dopants on magnesium oxide supported rare-earth oxide catalysts in the oxidative coupling of methane. Appl. Catal. A 528, 175-190. doi: 10.1016/j.apcata.2016.09.011

\section{AUTHOR CONTRIBUTIONS}

$\mathrm{MH}$ : worked on the experimental setup; YK and YN: conducted the experiments; AT: carried out the TEM analysis.

\section{ACKNOWLEDGMENTS}

This study was supported by a Grant-in-Aid for Scientific Research (No. 16K14046, 18K05294) from the Ministry of Education, Culture, Sports, Science and Technology of Japan.

Farrell, B. L., Igenegbai, V. O., and Linic, S. (2016). A viewpoint on direct methane conversion to ethane and ethylene using oxidative coupling on solid catalysts. ACS Catal. 6, 4340-4346. doi: 10.1021/acscatal.6b01087

Ferreira, V. J., Tavares, P., Figueiredo, J. L., and Faria, J. L. (2012). Effect of Mg, $\mathrm{Ca}$, and $\mathrm{Sr}$ on $\mathrm{CeO}_{2}$ based catalysts for the oxidative coupling of methane: investigation on the oxygen species responsible for catalytic performance. Ind. Eng. Chem. Res. 51, 10535-10541. doi: 10.1021/ie3001953

Ghose, R., Hwang, H. T., and Varma, A. (2014). Oxidative coupling of methane using catalysts synthesized by solution combustion method: Catalyst optimization and kinetic studies. Appl. Catal. A, 472, 39-46. doi: 10.1016/j.apcata.2013.12.004

Godini, H. R., Gili, A., Görke, O., Arndt, S., Simon, U., Thomas, A., et al. (2014). Sol-gel method for synthesis of $\mathrm{Mn}-\mathrm{Na}_{2} \mathrm{WO}_{4} / \mathrm{SiO}_{2}$ catalyst for methane oxidative coupling. Catal. Today 236, 12-22. doi: 10.1016/j.cattod.2014.01.005

Haneda, M., Kaneko, T., Kamiuchi, N., and Ozawa, M. (2015). Improved three-way catalytic activity of bimetallic Ir-Rh catalyst supported on $\mathrm{CeO}_{2}-\mathrm{ZrO}_{2}$. Catal. Sci. Technol. 5, 1792-1800. doi: 10.1039/c4cy01502a.

Haneda, M., Tanaka, M., Doi, Y., and Bion, N. (2018). Oxidative coupling of methane over Ba-doped $\mathrm{Y}_{2} \mathrm{O}_{3}$ catalyst - Similarity with active site for direct decomposition of NO. Mol. Catal. 457, 74-81.doi: 10.1016/j.mcat.2018.07.010

Hutchings, G. J., Scurrell, M. S., and Woodhouse, J. R. (1989). Oxidative coupling of methane using oxide catalysts. Chem. Soc. Rev. 18, 251-283. doi: $10.1039 /$ cs9891800251

Imagawa, H., Suda, A., Yamamura, K., and Sun, S. (2011). Monodisperse $\mathrm{CeO}_{2}$ nanoparticles and their oxygen storage and release properties. J. Phys. Chem. C 115, 1740-1745. doi: 10.1021/jp109878

Ito, T., Wang, J., Lin, C. H., and Lunsford, J. H. (1985). Oxidative dimerization of methane over a lithium-promoted magnesium oxide catalyst. J. Am. Chem. Soc. 107, 5062-5068. doi: 10.1021/ja00304a008

Ivanov, D. V., Isupova, L. A., Gerasimov, E., Yu., Dovlitova, L. S., Glazneva, T. S., et al. (2014). Oxidative methane coupling over $\mathrm{Mg}, \mathrm{Al}, \mathrm{Ca}, \mathrm{Ba}, \mathrm{Pb}$-promoted $\mathrm{SrTiO}_{3}$ and $\mathrm{Sr}_{2} \mathrm{TiO}_{4}$ : influence of surface composition and microstructure. Appl. Catal. A 485, 10-19. doi: 10.1016/j.apcata.2014.07.024 
Keller, G. E., and Bhasin, M. M. (1982). Synthesis of ethylene via oxidative coupling of methane. I. Determination of active catalysts. J. Catal. 73, 9-19. doi: 10.1016/0021-9517(82)90075-6

Kumar, G., Lau, S. L. J., Krcha, M. D., and Janik, M. J. (2016). Correlation of methane activation and oxide catalyst reducibility and its implications for oxidative coupling, ACS Catal. 6, 1812-1821. doi: 10.1021/acscatal.5b02657

Liang, Y., Li, Z., Nourdine, M., Shahid, S., and Takanabe, K. (2014). Methane coupling reaction in an oxy-steam stream through an $\mathrm{OH}$ radical pathway by using supported alkali metal catalysts. ChemCatChem 6, 1245-1251. doi: $10.1002 /$ cctc. 201400018

Lin, C. H., Campbell, K. D., Wang, J. X., and Lunsford, J. H. (1986). Oxidative dimerization of methane over lanthanum oxide. J. Phys. Chem. 90, 534-537. doi: 10.1021/j100276a004

Lunsford, J. H. (1995). The catalytic oxidative coupling of methane. Angew. Chem. Int. 34, 970-980. doi: 10.1002/anie.199509701

Martin, D., and Duprez, D. (1996). Mobility of surface species on oxides. 1. Isotopic exchange of ${ }^{18} \mathrm{O}_{2}$ with ${ }^{16} \mathrm{O}$ of $\mathrm{SiO}_{2}, \mathrm{Al}_{2} \mathrm{O}_{3}, \mathrm{ZrO}_{2}, \mathrm{MgO}, \mathrm{CeO}_{2}$, and $\mathrm{CeO}_{2}-\mathrm{Al}_{2} \mathrm{O}_{3}$. Activation by noble metals. Correlation with oxide basicity. J. Phys. Chem. 100, 9429-9438. doi: 10.1021/jp9531568

Pacheco Filho, J. G. A., Eon, J. G., and Schmal, M. (2000). Oxidative coupling of methane on $\mathrm{Ce} / \mathrm{Na} / \mathrm{CaO}$ catalysts. Catal. Lett. 68, 197-202. doi: 10.1023/A:1019064310606

Primet, M., and Garbowski, E. (2002). "Fundamentals and application of ceria in combustion reactions", in Catalysis by Ceria and Related Materials, ed A. Trovarelli (London: Imperial College Press), 407-429.

Rane, V. H., Chaudhari, S. T., and Choudhary, V. R. (2006). Comparison of the surface and catalytic properties of rare earth-promoted $\mathrm{CaO}$ catalysts in the oxidative coupling of methane. J. Chem. Technol. Biotechnol. 81, 208-215. doi: $10.1002 /$ jctb. 1387

Repelin, Y., Proust, C., Husson, E., and Beny, J. M. (1995). Vibrational spectroscopy of the C-form of yttrium sesquioxide. J. Solid State Chem. 118, 163-169. doi: 10.1006/jssc.1995.1326

Sekine, Y., Tanaka, K., Matsukata, M., and Kikuchi, E. (2009). Oxidative coupling of methane on Fe-doped $\mathrm{La}_{2} \mathrm{O}_{3}$ catalyst. Energy Fuels 23, 613-616. doi: $10.1021 /$ ef800665r.
Shannon, R. D. (1976). Revised effective ionic radii and systematic studies of interatomic distances in halides and chalcogenides. Acta. Cryst. A 32, 751-767. doi: $10.1107 /$ S0567739476001551

Takanabe, K. (2012). Catalytic conversion of methane: Carbon dioxide reforming and oxidative coupling. J. Jpn. Petrol. Inst. 55, 1-12. doi: 10.1627/jpi.55.1

Tang, L., Yamaguchi, D., Wong, L., Burke, N., and Chiang, K. (2011). The promoting effect of ceria on $\mathrm{Li} / \mathrm{MgO}$ catalysts for the oxidative coupling of methane. Catal. Today 178, 172-180. doi: 10.1016/j.cattod.2011.07.014

Trovarelli, A. (1996). Catalyti properties of ceria and $\mathrm{CeO}_{2}$-containing materials. Catal. Rev. Sci. Eng. 38, 439-520. doi: 10.1080/016149496080 06464

Ubaldini, A., and Carnasciali, M. M. (2008). Raman characterization of powder of cubic $\mathrm{RE}_{2} \mathrm{O}_{3}(\mathrm{RE}=\mathrm{Nd}, \mathrm{Gd}, \mathrm{Dy}, \mathrm{Tm}$, and $\mathrm{Lu}), \mathrm{Sc}_{2} \mathrm{O}_{3}$ and $\mathrm{Y}_{2} \mathrm{O}_{3}$. J. Alloy. Compd. 454, 374-378. doi: 10.1016/j.jallcom.2006.12.067

Xu, J., Peng, L., Fang, X., Fu, Z., Liu, W., Xu, X., et al. (2018). Developing reactive catalysts for low temperature oxidative coupling of methane: on the factors deciding the reaction performance of $\mathrm{Ln}_{2} \mathrm{Ce}_{2} \mathrm{O}_{7}$ with different rare earth $\mathrm{A}$ sites. Appl. Catal. A 552, 117-128. doi: 10.1016/j.apcata.2018.01.004

Yao, H. C., and Yao, Y. F. Y. (1984). Ceria in automotive exhaust catalysts. I. Oxygen storage. J. Catal. 86, 254-265. doi: 10.1016/0021-9517(84)90371-3

Yashima, M., Lee, J.-H., Kakihana, M., and Yoshimura, M. (1997). Raman spectral characterization of existing phases in the $\mathrm{Y}_{2} \mathrm{O}_{3}-\mathrm{Nb}_{2} \mathrm{O}_{5}$ system. J. Phys. Chem. Solids 58, 1593-1597. doi: 10.1016/S0022-3697(97)00098-X

Conflict of Interest Statement: The authors declare that the research was conducted in the absence of any commercial or financial relationships that could be construed as a potential conflict of interest.

Copyright (c) 2018 Haneda, Katsuragawa, Nakamura and Towata. This is an openaccess article distributed under the terms of the Creative Commons Attribution License (CC BY). The use, distribution or reproduction in other forums is permitted, provided the original author(s) and the copyright owner(s) are credited and that the original publication in this journal is cited, in accordance with accepted academic practice. No use, distribution or reproduction is permitted which does not comply with these terms. 